\title{
8. DATA REPORT: THE OLIGOCENE SEWELL POINT AND ATLANTIC CITY FORMATIONS, NEW JERSEY COASTAL PLAIN ${ }^{1}$
}

\author{
Stephen F. Pekar, ${ }^{2}$ Kenneth G. Miller, ${ }^{2,3}$ and Richard K. Olsson ${ }^{2}$
}

\begin{abstract}
We formally name the Sewell Point and Atlantic City Formations, two distinct Oligocene lithologic units identified in subsurface strata in New Jersey. These formations are stratotypified at the Ocean Drilling Program Leg 150X Atlantic City and Cape May boreholes. The lower to upper Oligocene Sewell Point Formation consists of glauconitic clays and silts and clayey glauconite sand. It can be differentiated from the underlying clays of the Absecon Inlet Formation (upper Eocene) by its coarser grain size. The upper Oligocene Atlantic City Formation consists of medium- to coarse-grained glauconitic quartz sands and subordinate glauconitic clays and silts that overlie the Sewell Point Formation. It can be differentiated from the Sewell Point Formation by its coarser grain size, especially its high medium to coarse quartz sand content ( $>10 \%$, with typical values of $\sim 50 \%$ vs. trace amounts in Sewell Point Formation). The glauconitic Atlantic City Formation is readily differentiated from overlying quartz sands and micaceous silty clays of the Kirkwood Formation. Of the six Oligocene sequences recognized in the subsurface by integrated stratigraphy, four (1-4) are restricted to the Sewell Point Formation, whereas two (O5, O6) span both formations, emphasizing the differences between these lithostratigraphic and sequence stratigraphic units.
\end{abstract}

\section{INTRODUCTION}

Despite over $150 \mathrm{yr}$ of study of New Jersey Coastal Plain strata (Lyell, 1845), Oligocene sediments were not recognized in this region until recently (Brown et al., 1972; Olsson et al., 1980). In outcrop, the silty clays and sands of the lower Miocene Kirkwood Formation unconformably overlie the middle Eocene Shark River Formation. Although sands are found above this disconformity on the Manasquan River near Allaire (Fig. 1; Sugarman et al., 1991), they are unfossiliferous, and their age is unknown. Subsurface wells and boreholes provided the first indication of the presence of Oligocene glauconitic quartz sands and occasional silts (Miller, 1978; Olsson and Miller, 1979; Olsson et al., 1980). These strata were first identified at the discontinuously cored Leggette and Jobs Point boreholes as well as older rotary wells (e.g., the Island Beach and Anchor Dickinson-1) and were assigned to Oligocene planktonic foraminiferal Zones P20-P22 (Olsson and Miller, 1979; Olsson et al., 1980). Poag (1985) subsequently identified Oligocene sediments at the AMCOR 6011 and the Anchor Dickinson-1 well (Fig. 1), and noted the possible presence of Oligocene strata at a previously drilled well at Island Beach. Oligocene strata were identified also at the ACGS \#4 borehole, Mays Landings, New Jersey (Owens et al., 1988; Fig. 1). Lower Oligocene glauconitic silts and sands (31 ft [9.4 m]) and upper Oligocene quartz sands ( $90 \mathrm{ft}$ thick [27.4 m]) were dated at the ACGS \#4 using strontium isotopes as $\sim 33 \mathrm{Ma}$ and $\sim 27 \mathrm{Ma}$, respectively (Miller et al., 1990).

The formational assignment of Oligocene strata has been controversial. Miller (1978) termed the upper Oligocene sands and silts the Jobs Point unit from the Job Point, New Jersey borehole, but did not formally publish the name of the Oligocene sands. The U.S. Geological Survey (Nemickas and Carswell, 1976) mapped upper Oligocene aquifer sands in New Jersey and termed them the Piney Point Aquifer. Olsson et al. (1980) subsequently applied the name Piney Point to the upper Oligocene glauconite and quartz sands and silts in New Jersey. However, the Piney Point Formation was named for supposedly upper Eocene ("Jackson age") sands in Maryland by Otten

${ }^{1}$ Miller, K.G., and Snyder, S.W. (Eds.), 1997. Proc. ODP, Sci. Results, 150X: College Station. TX (Ocean Drilling Program)

${ }^{2}$ Department of Geological Sciences, Rutgers University, P.O. Box 1179, Piscataway, NJ 08855-1179, U.S.A. spekar@ rci.rutgers.edu ${ }^{3}$ Lamont-Doherty Earth Observatory of Columbia University, Palisades, NY 10964 ,
U.S.A.
(1955). Subsequent study of the Piney Point Formation by Benson (1978) revealed that the type Piney Point Formation is middle Eocene and differs from the upper Oligocene glauconite and quartz sands and silts in New Jersey. Owens et al. (1988) informally recognized the lowermost Oligocene Mays Landing unit and the upper Oligocene Beta unit at the ACGS\#4 borehole (Fig. 1). However, the overall poor fossil preservation of the lower Oligocene section and the poor recovery of the upper Oligocene sands ( $\sim 5 \%$ recovery) limited the use of the ACGS\#4 borehole in stratotypifying these units. Therefore, more complete and well-preserved sections were needed to properly differentiate formations within New Jersey Oligocene strata.

During 1993-1994, Ocean Drilling Program (ODP) Leg 150X drilled three onshore boreholes at Island Beach, Atlantic City, and Cape May (Fig. 1), recovering $192 \mathrm{ft}(58.6 \mathrm{~m}), 267 \mathrm{ft}(81.4 \mathrm{~m})$, and $179 \mathrm{ft}(54.6 \mathrm{~m})$ respectively, of Oligocene strata. Initial reports (Miller, et al., 1994, 1996) and subsequent studies (Pekar, 1995; Pekar et al., Chapter 15, this volume) provide lithologic, biostratigraphic, $\mathrm{Sr}-$ isotopic data, and sequence stratigraphic interpretations of the Oligocene in the Leg $150 \mathrm{X}$ boreholes. We use these data to map and define the Sewell Point and Atlantic City Formations. The Sewell Point is stratotypified in the Leg 150X Cape May borehole that was drilled on Sewell Point, Cape May, New Jersey, adjacent to the Cape May Inlet (Fig. 2). The Sewell Point Formation at Cape May is represented by a relatively thick section $(98 \mathrm{ft}[29.9 \mathrm{~m}])$, with good recovery (80.4\%), and good microfossil preservation (Pekar et al., Chapter 15, this volume). The Atlantic City Formation is stratotypified in the Leg 150X Atlantic City borehole (Fig. 3) where it is $106 \mathrm{ft}$ thick (32.3 m), is moderately recovered (45.2\%), and has well-preserved calcareous microfossils (Pekar et al., Chapter 15, this volume).

\section{RESULTS \\ Sewell Point Formation}

\section{Lithology}

The Sewell Point Formation type section at the Cape May borehole (1360-1262 ft [414.5-384.7 m]; Fig. 2) overlies the upper Eocene Absecon Inlet Formation. The Sewell Point Formation consists primarily of glauconitic sandy silty clay and clayey fine glauconite sand. 


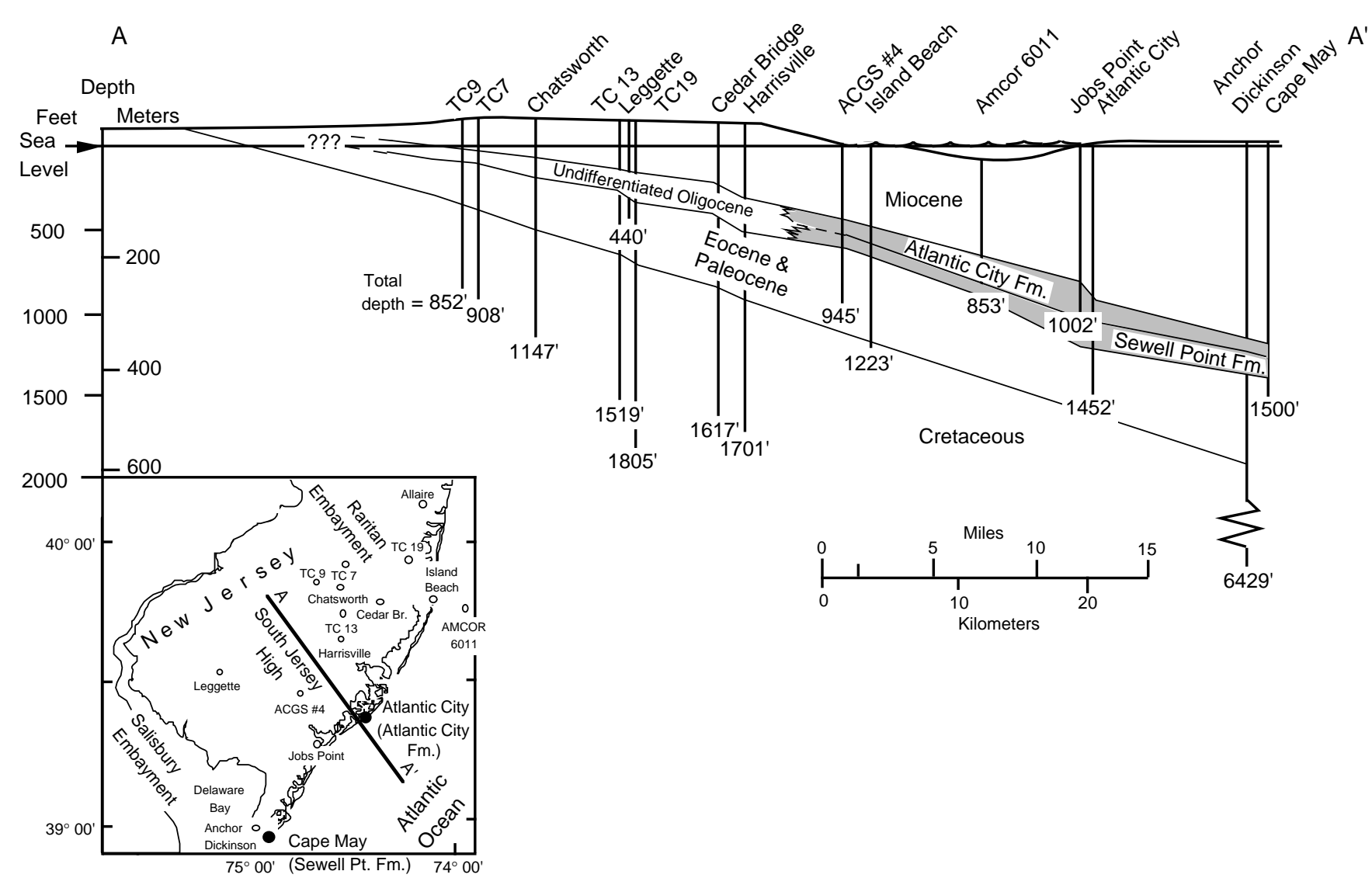

Figure 1. Cross section parallel to dip showing the Sewell Point Formation and the Atlantic City Formation and depths and locations of wells (modified after Olsson et al., 1980). Inset is New Jersey base map indicating locations of boreholes and structural provinces.

The basal contact of the stratotype occurs in an interval of no recovery between 1360 and $1354.5 \mathrm{ft}$ (414.5 and $412.9 \mathrm{~m}$ ). Laminated firm silty clays occur below the contact and shells grading into olivegray clayey glauconite sand occurs above it. A sharp upsection increase in the gamma-ray $\log$ at $1360 \mathrm{ft}(414.5 \mathrm{~m})$ represents the lithologic contact with uniform clays below and "hot" glauconites above (Miller, et al., 1996).

At the stratotype, the lithology is dominantly dark brownish gray to olive gray glauconitic silty clays. The subdominant lithology is dark olive brown clayey fine glauconite sand, with the highest abundances of glauconite in the lower part of sequences (Fig. 2). Low amounts of fine-grained quartz sand $(0 \%-10 \%)$ are found in the Sewell Point Formation (Fig. 2). A shell bed marks the base of the recovered section and shell material above this is uncommon at the stratotype, although shells are found at several levels within this formation at Atlantic City. Bedding ranges from massive to finely laminated with occasional burrows. Within the Sewell Point Formation, several stratal boundaries associated with facies changes are interpreted as disconformities $(1350,1315,1305$, and $1300 \mathrm{ft}[411.5$, 400.8, 397.8, and 396.2 m], respectively; see Pekar et al., Chapter 15, this volume for discussion). These sequences generally consist of basal glauconite sands overlain by glauconitic silts (Fig. 2).

Repeated small-scale cyclic successions occur in the upper part of the stratotype. Three coarsening upward successions are found from 1300 to $1290.6 \mathrm{ft}(397.8-393.2 \mathrm{~m}), 1290.6$ to $1279.0 \mathrm{ft}(393.2-389.8$ $\mathrm{m})$, and 1279.0 to $1274.9 \mathrm{ft}(389.8-388.6 \mathrm{~m})$, consisting of basal glauconitic sandy clays, medial glauconitic silts, and upper glauconitic quartzose sandy silts. This small-scale cyclicity is revealed by the gamma ray log and general lithologic descriptions, although sampling for the cumulative percentage diagram is too coarse to discern these cycles. They are interpreted as parasequences (see Pekar et al., Chapter 15, this volume for discussion).

\section{Age}

Based on planktonic foraminifers and Sr-isotopic age estimates, the Sewell Point Formation extends from the earliest Oligocene (33.5 Ma using the timescale of Berggren et al., 1995) to late Oligocene (25.0 Ma; Pekar et al., Chapter 15, this volume; Fig. 2) at the type section. The lower part of the stratotype (1360-1350.8 ft [414.5$411.5 \mathrm{~m}]$ ) is assigned to Zone P18 based on the highest occurrence of Hantkenina spp. and Turborotalia cerroazulensis at $1360 \mathrm{ft}(414.5$ m) and the highest occurrence of Pseudohastigerina spp. at $1350.8 \mathrm{ft}$ (Liu et al., Chapter 10, this volume). The section from 1350.8 to $1314.8 \mathrm{ft}(411.7-400.8 \mathrm{~m})$ at the stratotype is placed within Biochron P19 of Berggren et al. (1995) based on the highest occurrence of Pseudohastigerina spp. at $1350.8 \mathrm{ft}(411.7 \mathrm{~m})$, and strontium age estimates of 31.6 and 30.1 Ma (Pekar et al., Chapter 15, this volume).

A 2.0-m.y. hiatus (30.1 and 28.1 Ma) based on strontium age estimates is associated with an unconformity at $1314.8 \mathrm{ft}(400.8 \mathrm{~m})$. Between 1314.8 and $1304.8 \mathrm{ft}$ (400.8 and $397.7 \mathrm{~m}$ ), two strontium age estimates of 28.3 and $28.1 \mathrm{Ma}$ at 1308.8 and $1305.8 \mathrm{ft}$ (398.9 and $398.0 \mathrm{~m}$ ) indicate correlation to Biochron P21.

An unconformity at $1304.8 \mathrm{ft}(397.7 \mathrm{~m})$ is associated with a 1.4m.y. hiatus based on Sr-isotopic age estimates of 28.1 Ma below and 26.7 Ma above. The section above is dated by Sr-isotopic age estimates of $25.7 \mathrm{Ma}$ at 1300 and $1302 \mathrm{ft}$ (396.2 and $396.8 \mathrm{~m})$ and 26.7 Ma at $1303.8 \mathrm{ft}$ (398.0 m) at Cape May.

The section from 1300 to $1262 \mathrm{ft}(396.2-384.7 \mathrm{~m})$ lies above the highest occurrence of $P$. opima opima, and below the lowest occur- 


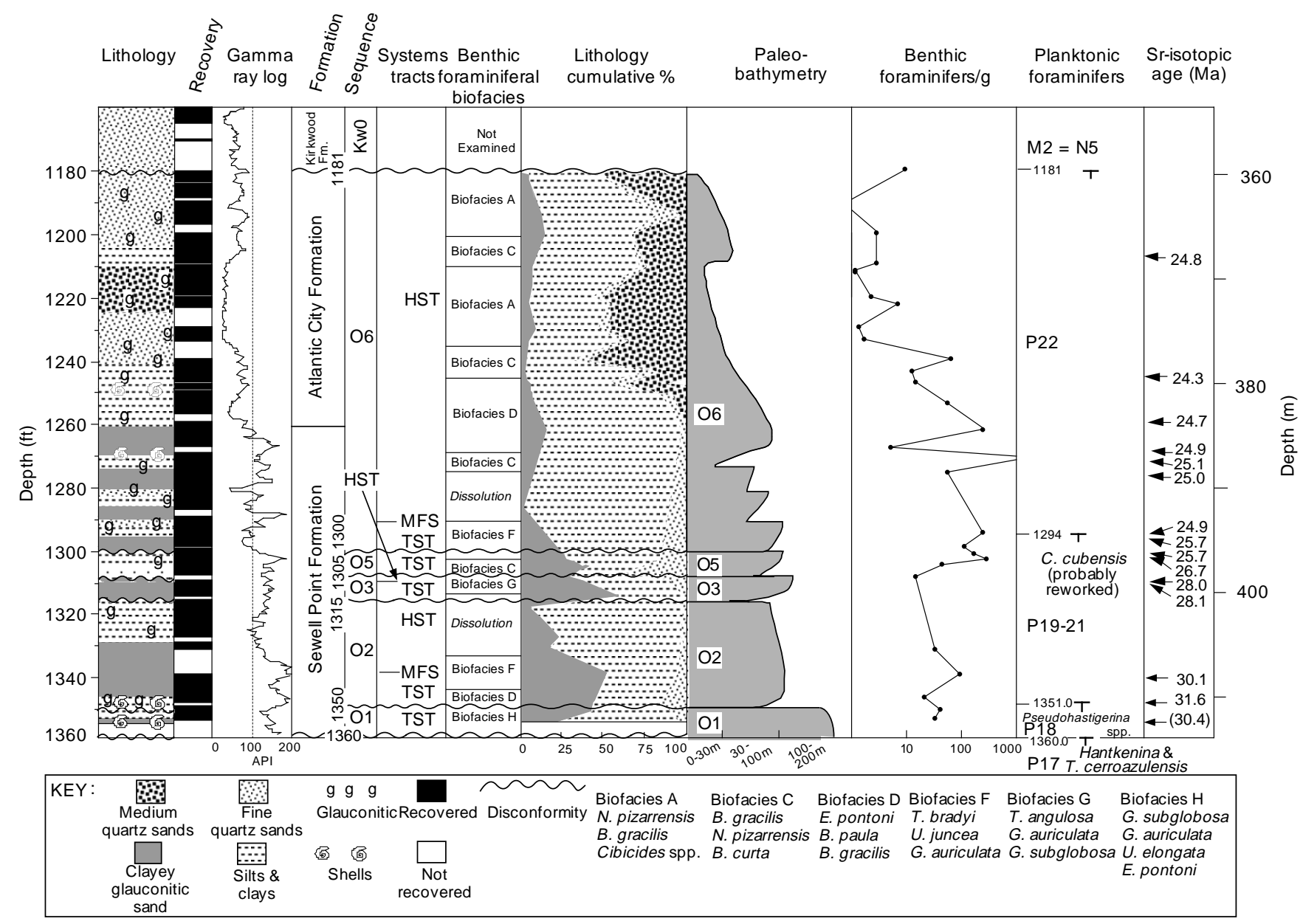

Figure 2. Stratigraphic column of Sewell Point and Atlantic City Formations at Cape May (from Pekar et al. [Chapter 15, this volume]).

rence of Miocene taxa, placing it in Zone P22. Five Sr-isotopic age estimates range from 25.0 to $24.8 \mathrm{Ma}$, consistent with the biostratigraphic correlation.

\section{Benthic Foraminifers and Environments of Deposition}

Benthic foraminiferal and lithofacies studies provide bathymetric estimates indicating that the Sewell Point Formation at both Cape May and Atlantic City was deposited mainly in a middle to outer neritic environment (Pekar et al., Chapter 15, this volume). This indicates that the lower sections of the Oligocene were deposited in deeper waters than the upper Oligocene Atlantic City Formation, which was deposited in mainly middle to inner neritic environments.

Benthic foraminifers assemblages from the Sewell Point Formation at Cape May are relatively diverse ( $>20$ species per sample) and abundant (>100 specimens per gram of sample; Pekar, 1995). Two distinct groups of biofacies are observed within the formation at Cape May. One (Biofacies F, G, and H; Fig. 2; Pekar et al., Chapter 15, this volume) is indicative of middle to outer neritic environments and the other (Biofacies C and D; Pekar et al., Chapter 15, this volume) represents outer inner to inner middle neritic environments (Fig. 2). Middle to outer neritic species dominate most of the section and include Globocassidulina subglobosa, Trifarina angulosa, Trifarina bradyi, Globobulimina auriculata, Uvigerina juncea, and Uvigerina nuttalli (Pekar, 1995). Biofacies C and D (Fig. 2) contain shallower water species such as Buliminella curta, Bulimina gracilis, Bolivina paula, and Nonionellina pizarrensis (Pekar et al., Chapter 15, this volume).

Glauconite found in the Sewell Point Formation at the stratotype was primarily deposited in situ in middle to outer neritic environments, in contrast to the Atlantic City Formation, which contains abundant detrital glauconite (Pekar et al., Chapter 15, this volume). Detrital glauconites are found in the Sewell Formation at Island Beach (see below).

\section{Sequence Stratigraphy}

The Sewell Point Formation can be divided into five sequences at Cape May: Sequence O1 (1360-1350.8 ft [414.5-411.7 m]), Sequence O2 (1350.8-1305.8 ft [414.5-398.0 m]), Sequence O3 (1314.8-1304.8 ft [400.8-397.7 m]), Sequence O5 (1304.8-1300.0 ft [397.7-396.2 m]), and the lower part of Sequence O6 (1300-1262 ft [396.2-384.7 m]; Fig. 2). One additional sequence encompassed by the Sewell Point Formation, O4, is represented only at Atlantic City (1138-1072 ft [346.9-326.7 m]; Pekar et al., Chapter 15, this volume). Details of these sequences are discussed in Pekar et al. (Chapter 15 , this volume).

\section{Atlantic City Formation}

\section{Lithology}

The Atlantic City Formation type section, located at the Atlantic City borehole, overlies the Sewell Point Formation, and extends from 


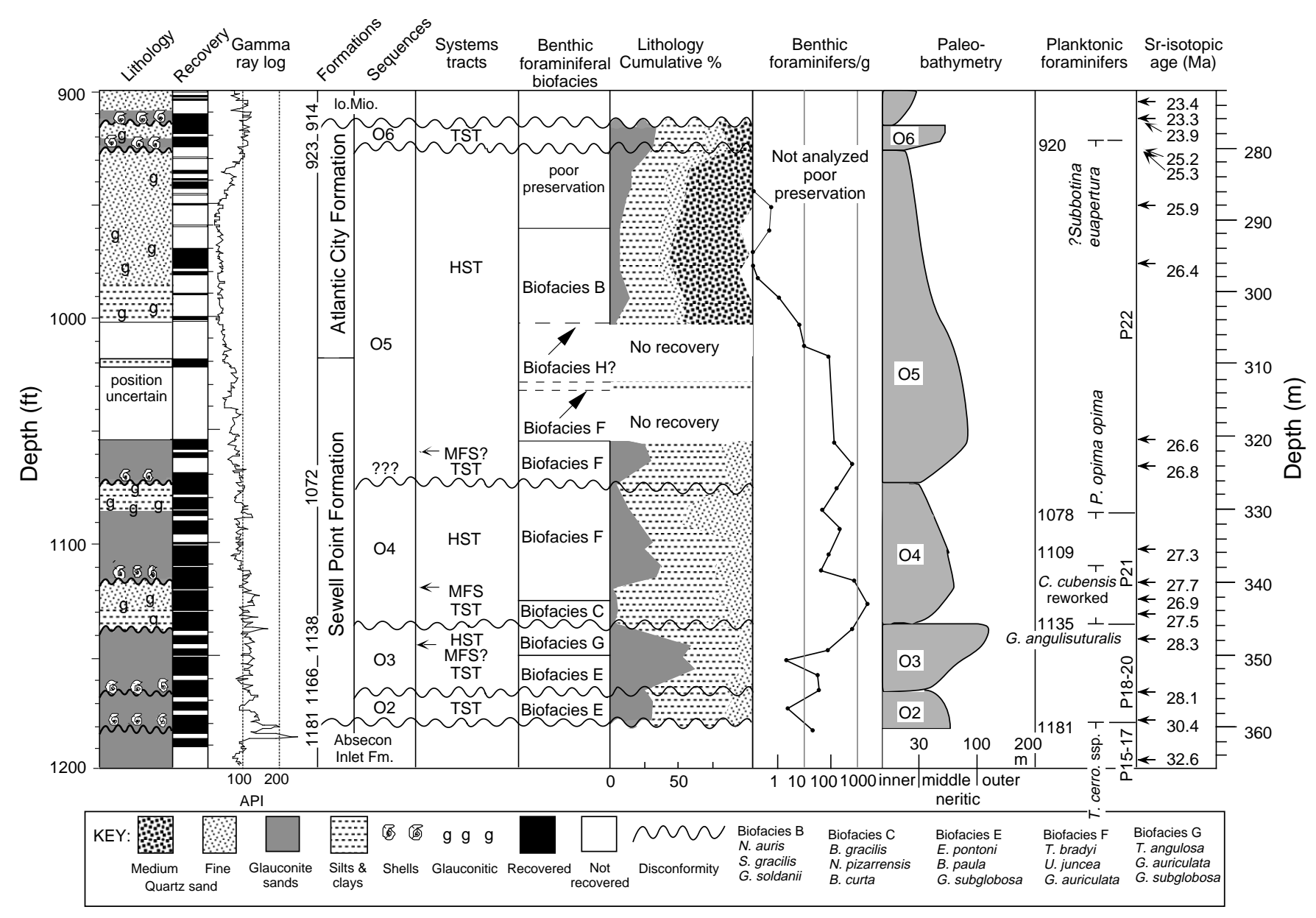

Figure 3. Stratigraphic column of Atlantic City Formation at Atlantic City (from Pekar et al. [Chapter 15, this volume]).

$\sim 1010$ to 914 ft (307.9-278.6 m; Fig. 3). The Atlantic City Formation at the stratotype consists primarily of olive gray glauconitic clayey to silty medium- to coarse-grain quartz sand often containing shell fragments (Fig. 3). The basal contact at Atlantic City is not recovered; however, increasing gamma-ray log values down section indicate that it probably occurs between 1012 and $1020 \mathrm{ft}$ (308.5 and 310.9 m). At Cape May, the contact between the Sewell Point Formation and Atlantic City Formation (1262 ft [384.7 m]) is intact and is recognized by clayey glauconite sand below and glauconitic clays and silts that coarsen upward to glauconitic fine- to medium-grain quartz sands. Therefore, we stratotypify the lower boundary for the Atlantic City Formation at the Cape May borehole. The level chosen at Cape May for the base (1262 ft [384.7 m]) marks the first increase in medium to coarse quartz sands (Fig. 2). Thus, the base of the formation consists of slightly sandy glauconitic clays and silts that coarsen upsection.

The upper contact of the Atlantic City Formation occurs at 914.2 $\mathrm{ft}(278.6 \mathrm{~m})$ at the base of a second shell bed (914.2-911.3 $\mathrm{ft}$ [278.6$277.8 \mathrm{~m}]$ ). The overlying section consists of basal glauconite sands of the Kirkwood Formation ( $\mathrm{Kw} 0$ sequence), which are in turn overlain by typical Kirkwood silty clays and quartz sands.

At the stratotype at Atlantic City, the lithology is dominantly medium and coarse sand that ranges from $44 \%$ to $58 \%$ in the lower part (1000-923 ft [304.8-281.3 m]; within Sequence O6; Fig. 3) to 10\%$20 \%$ in the upper part (923-914 ft [281.3-278.6 m]; with Sequence O5; Fig. 3). A shell bed occurs between 923 and $922.4 \mathrm{ft}$ (281.3 and
$281.1 \mathrm{~m})$. Shell fragments are found throughout the stratotype section. Bedding in these sands appears to be massive. Within the Atlantic City Formation stratotype, only one stratal boundary associated with a facies changes is interpreted as disconformity (923 ft [281.3 m]; Fig. 3).

Unusual, brown botryoidal grains were first observed in the upper Oligocene Atlantic City Formation at the Jobs Point and Leggette boreholes (Miller, 1978; Olsson et al., 1980). Pekar et al. (Chapter 15, this volume) note that these grains are goethite and an undifferentiated clay mineral and interpret these grains as weathered, recycled detrital glauconite deposited in highstand systems tracts.

\section{Age}

Based on Sr-isotopic age estimates, the Atlantic City Formation at the stratotype extends from the late Oligocene (26.6 Ma) to the latest Oligocene (25.0 Ma; Pekar et al., Chapter 15, this volume). Six strontium-isotope age estimates that range from $26.3 \pm 0.8 \mathrm{Ma}(974 \mathrm{ft}$ [296.9 m]) to $25.2 \pm 0.8 \mathrm{Ma}(922.5 \mathrm{ft}[281.1 \mathrm{~m}])$ correlate this interval to Biochron P22. There are no age-diagnostic planktonic foraminifers for this section. Calcareous nannofossils are scarce with generally limited preservation; however, the formation can be assigned to undifferentiated Zones NP24-25 (29.9-23.9 Ma), based on the presence of Reticulofenstra bisecta and Helicosphaera recta, and the absence of Sphenolithus spp. (Miller et al., 1994). 


\section{Benthic Foraminifers and Environments of Deposition}

Benthic foraminiferal biofacies and lithofacies analyses demonstrate that the stratotype Atlantic City Formation was deposited in a middle to inner neritic environment. The Atlantic City Formation at the stratotype can be divided into two depositional regimes; (1) a shoaling upward succession (1020-923 ft [310.9-281.3 m]), and (2) a deepening upward succession (923-914 ft [281.3-278.6 m]; Fig. 3).

From 1010 to $923 \mathrm{ft}(307.8-281.3 \mathrm{~m})$, the lithology indicates a shoaling upward succession (middle to inner neritic) as indicated by a clay increase from 1020 to $1010 \mathrm{ft}(310.9-307.8 \mathrm{~m})$ and an increase in quartz sands above $1010 \mathrm{ft}(307.8 \mathrm{~m})$ to the top of the unit $(923 \mathrm{ft}$ [281.3 m]). A sequence (O6) from 923 to $914 \mathrm{ft}(281.3-278.6 \mathrm{~m})$ consisting of shells at the base overlain by glauconite sand indicates a rapid deepening from inner neritic to at least middle neritic. The sequence is thin and does not contain the typical upper silts and sands (Pekar et al., Chapter 15, this volume), suggesting that it has been truncated.

Benthic foraminiferal biofacies studies support interpretations based on lithofacies studies. Above $1001 \mathrm{ft}(305.1 \mathrm{~m})$, the biofacies contains an assemblage (Nonionellina auris and Spiroplectammina gracilis) that indicates inner neritic environments. Benthic foraminifers are absent between 957 and $923 \mathrm{ft}$ (291.7 and $281.3 \mathrm{~m}$ ) because of dissolution. Between 923 and $914 \mathrm{ft}$ (281.3 and $278.6 \mathrm{~m}$ ), a deepening to middle neritic paleodepths is indicated by a biofacies assemblage consisting of Cibicides primulus and Bulimina gracilis.

\section{Sequence Stratigraphy}

The stratotype for the Atlantic City Formation encompasses two sequences: the upper part of Sequence O5 (1020-923 ft [310.9-281.3 m]), and O6 (923-914 ft [281.3-278.6 m]; Fig. 3). At Cape May, the formation consists of the upper Highstand Systems Tracts of Sequence O6. Pekar et al. (Chapter 15, this volume) provide detailed discussions of the facies changes and stratal surfaces associated with these sequences.

\section{DISCUSSION}

\section{Variations of the Sewell Point Formation in New Jersey}

The Sewell Point Formation has not been identified in outcrop and apparently pinches out in the subsurface. It forms a thickening wedge basinward, attaining a thickness of up to $\sim 160 \mathrm{ft}(48.8 \mathrm{~m})$ below the present coastline (Miller, et al., 1994, 1996; Figs. 1, 4).

The similarities observed in the Sewell Point Formation between the Atlantic City borehole and the Cape May borehole are illustrated by a fence diagram that shows the lithologies among the three boreholes along with the preservation and truncation of the different sequences (Fig. 4). At Atlantic City and Island Beach, the lithofacies and biofacies generally indicate middle to outer neritic depositional environments for the Sewell Point Formation (Pekar et al., Chapter 15 , this volume). However, whereas the Sewell Point Formation at Island Beach contains both sequences, $\mathrm{O} 1$ and $\mathrm{O} 2$, at Atlantic City the $\mathrm{O} 1$ sequence is missing, but contains a sequence $(\mathrm{O} 4)$ not recognized at Cape May. The $\mathrm{O} 4$ sequence at Atlantic City is dated by planktonic foraminifers and $\mathrm{Sr}$-isotope stratigraphy as an earliest late Oligocene sequence, correlating it to Zone P21b (27.5-28.3 Ma; Pekar et al., Chapter 15, this volume). Another significant difference is the placement of the Sewell Point/Atlantic City formational contact in different sequences. At Cape May, the contact occurs in the lower third of Sequence O6; however, at Atlantic City, the contact occurs in the

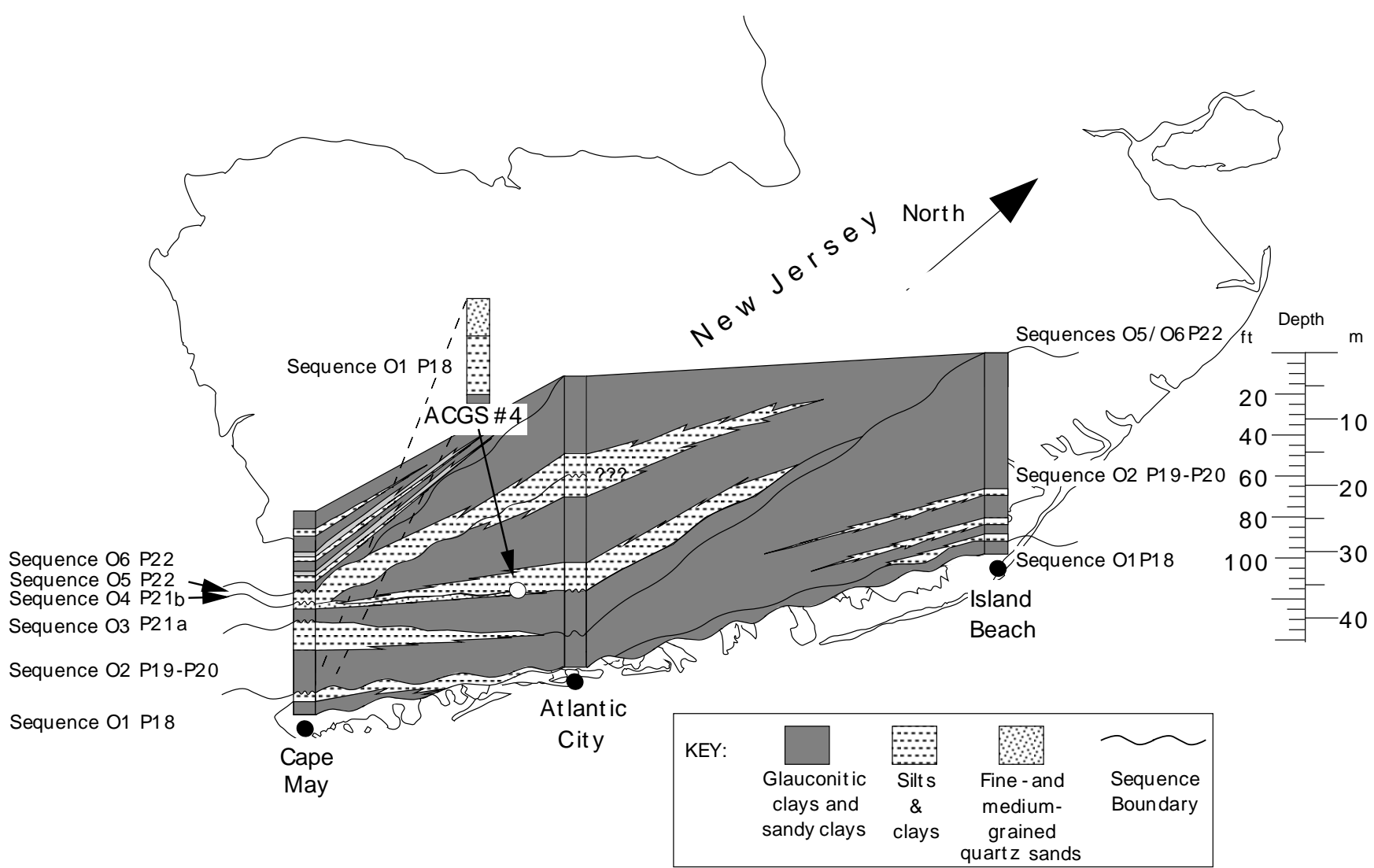

Figure 4. Fence diagram of the Sewell Point Formation as observed in the Leg 150X and ACGS \#4 boreholes. The formation is divided into planktonic foraminiferal zones and New Jersey Oligocene sequences (from Pekar et al. [Chapter 15, this volume]). 
middle of Sequence O5. This indicates that the deposition of the thick sand unit of the Atlantic City Formation at Atlantic City began 1 m.y. earlier than at Cape May.

Owens et al. (1988) applied the informal name Mays Landing unit to the lower Oligocene at ACGS \#4 borehole. The Mays Landing unit is here placed in the Sewell Point Formation. However, the Mays Landing unit may be slightly older (Zone P18 and NP21; Poore and Bybell, 1988) than the Sewell Point Formation at the Cape May stratotype section, and it may represent an older sequence than $\mathrm{O} 1$ of Pekar et al. (Chapter 15, this volume). It also differs significantly in lithology from the Sewell Point Formation in the three Leg 150X boreholes (Fig. 4). Although the Sewell Point Formation at ACGS \#4 contains some glauconite sand at the base of the formation ( $9 \mathrm{ft}[3$ $\mathrm{m}]$ ), the lithology quickly changes to a very fine micaceous sand with scattered pieces of lignitized wood (Owens et al., 1988) and grades to glauconite micaceous quartz sand with wood pieces common through the upper two thirds of the formation. The Mays Landing unit was deposited in shallower paleoenvironments than the downdipped Sewell Point Formation; sparse, high dominant benthic foraminiferal biofacies ( $N$. pizarrensis) indicate inner neritic depths in part of the Mays Landing unit (Christensen et al., 1995), and lithofacies analysis suggests that the section shallows to nearshore paleodepths (Owens et al., 1988).

\section{Variations of the Atlantic City Formation in New Jersey}

The upper Oligocene Atlantic City Formation has not been identified in outcrop and appears to pinch out in the subsurface. However, unfossiliferous glauconitic sands have been observed below the Miocene Kirkwood Formation and above the upper Shark River Formation in outcrops (e.g., near Allaire State Park, Sugarman et al., 1991), which may represent this formation. The Atlantic City Formation forms a basinward thickening wedge, attaining a thickness up to $\sim 106$ $\mathrm{ft}(32.3 \mathrm{~m})$ below the present coastline near Atlantic City (Miller, et al., 1994, 1996; Figs. 1, 5). It extends further updip than the lower Oligocene Sewell Point Formation, as observed at the Leggette and ACGS \#4 boreholes.

There are significant lithologic differences among the different boreholes. The Atlantic City Formation at Atlantic City is thicker than at the Cape May $(81 \mathrm{ft}[24.7 \mathrm{~m}])$ and the Island Beach $(97 \mathrm{ft}$ [29.6 m]) boreholes. This difference is illustrated by a fence diagram (Fig. 5). The upper Atlantic City Formation quartz sands thicken near Atlantic City and show less variability than at either Cape May or Island Beach. Updip wells do not contain the lower clays observed at Cape May (e.g., ACGS \#4 and Leggette boreholes, Fig. 2). At Island Beach, the lithology generally consists of reworked brown glauconite sand that is equivalent to the Atlantic City Formation sands.

At Atlantic City, two upper Oligocene sequences (O5 and O6) are recognized. However, Sequence O5 is thick near Atlantic City, but appears to thin southward toward Cape May and updip toward the ACGS \#4 boreholes. At Island Beach, the age control and recovery of the upper Oligocene are too poor to determine extent of Sequence O5 northward.

It is difficult to differentiate between the Sewell Point and the Atlantic City Formations at Island Beach. We tentatively place the contact at $602 \mathrm{ft}(183.5 \mathrm{~m})$ based on integrated correlations. Medium to coarse quartz sands are less abundant at this site than downdip or along strike to the south (Fig. 5), making the primary criterion of medium to coarse quartz sands difficult to apply. We place the boundary between Sequences O6 and O2 at Island Beach, reflecting slightly elevated amounts of quartz sand in Sequence O6 (see fig. 6 in Pekar et al., Chapter 15, this volume). In contrast, Owens et al. (Chapter 2, this volume) place the lithologic contact at $657 \mathrm{ft}(200.2 \mathrm{~m})$ at the base of a section containing weathered brown glauconite. As noted, this brown glauconite is detrital in origin. The lower amounts of quartz sand in Sequence O6 near Island Beach reflects a difference in source at this time, because sections to the south contain abundant mediumcoarse quartz sand (Fig. 5). Despite these problems in mapping the difference between the formations in the north, comparisons of the distributions of the formations (cf., Figs. 4 and 5) show clear differences that are readily recognized in the New Jersey Coastal Plain to the south of Island Beach.

\section{ACKNOWLEDGMENTS}

We thank L. Bybell, P. Sugarman, and J. Browning for discussion in naming the Oligocene of New Jersey. The late J. Owens first recognized that the Oligocene of New Jersey can be divided into two units; we thank him for his inspiration. L. Bybell prompted us to finally name these units. We thank J.V. Browning, R.M. Leckie, and P. Sugarman for reviews. We were supported by NSF Grants EAR9218210 and EAR94-17108. This is LDEO contribution 5661.

\section{REFERENCES}

Benson, R.N., 1978. Oligocene rocks in the subsurface of Delaware. Geol. Soc. Am., Northeastern Sect., 24:4. (Abstract)

Berggren, W.A., Kent, D.V., Swisher, C.C., III, and Aubry, M.-P., 1995. A revised Cenozoic geochronology and chronostratigraphy. In Berggren, W.A., Kent, D.V., Aubry, M.-P., and Hardenbol, J. (Eds.), Geochronology, Time Scales and Global Stratigraphic Correlation. Publ.-Soc. Econ. Paleontol. Mineral., 54:129-212.

Brown, P.M., Miller, J.A., and Swain, F.M., 1972. Structural and stratigraphic framework, and spatial distribution of permeability of the Atlantic Coastal Plain, North Carolina to New York. Geol. Surv. Prof. Pap. U.S., 175-A:1-50.

Christensen, B.A., Miller, K.G., and Olsson, R.K., 1995. Eocene-Oligocene benthic foraminiferal biofacies and depositional sequences at the ACGS\#4 borehole, New Jersey coastal plain. Palaios, 10:103-132.

Lyell, C., 1845. The Cretaceous strata of New Jersey. Quat. J. Geol. Soc. London, 1: 55-60.

Miller, K.G., 1978. Paleogene Subsurface Stratigraphy and the Paleoecology of the Jobs Point Formation (upper Oligocene) Formation New Jersey Coastal Plain [Senior Thesis]. Rutgers Univ.

Miller, K.G., et al., 1994. Proc. ODP, Init. Repts. 150X: College Station, TX (Ocean Drilling Program).

Miller, K.G., et al., 1996. Proc. ODP, Init. Repts., 150X (Suppl.): College Station, TX (Ocean Drilling Program).

Miller, K.G., Kent, D.V., Brower, A.N., Bybell, L.M., Feigenson, M.D., Olsson, R.K., and Poore R.Z., 1990. Eocene-Oligocene sea-level changes on the New Jersey coastal plain linked to the deep-sea record. Geol. Soc. Am. Bull., 102:331-339.

Nemickas, B., and Carswell, L.D., 1976. Stratigraphic and hydrologic relationship of the Piney Point aquifer and the Alloway Clay Member of the Kirkwood Formation in New Jersey. U.S. Geol. Surv. J. Res., 1:1-7.

Olsson, R.K., and Miller, K.G., 1979. Oligocene transgressive sediments of New Jersey continental margin. Am. Assoc. Petrol. Geol. Bull., 63:505.

Olsson, R.K., Miller, K.G., and Ungrady, T.E., 1980. Late Oligocene transgression of the middle Atlantic coastal plain. Geology, 8:549-554.

Otten, E.G., 1955. Ground-water resources of the southern Maryland coastal plain. Maryland Nat. Res. Board Bull., 15:1-347.

Owens, J.P., Bybell. L.M., Paulachok, G., Ager, T.A., Gonzalez, V.M., and Sugarman, P.J., 1988. Stratigraphy of the Tertiary sediments in a 945foot-deep core hole near Mays Landing in the southeastern New Jersey Coastal Plain. Geol. Surv. Prof. Pap. U.S., 1484.

Pekar, S.F., 1995. New Jersey Oligocene sequences recorded at the Leg 150X boreholes (Cape May, Atlantic City, and Island Beach)[M.S. thesis]. Rutgers Univ., Piscataway, NJ.

Poag, C.W., 1985, Cenozoic and upper Cretaceous sedimentary facies and depositional systems of the New Jersey slope and rise. In Poag, C.W. (Ed.). Geological Evolution of the United States Atlantic Margin: New York (Van Nostrand Reinhold), 343-365.

Poore, R.Z., and Bybell, L.M., 1988. Eocene to Miocene biostratigraphy of New Jersey core ACGS\#4: implications for regional stratigraphy. U.S. Geol. Surv. Bull., 1829:1-22. 


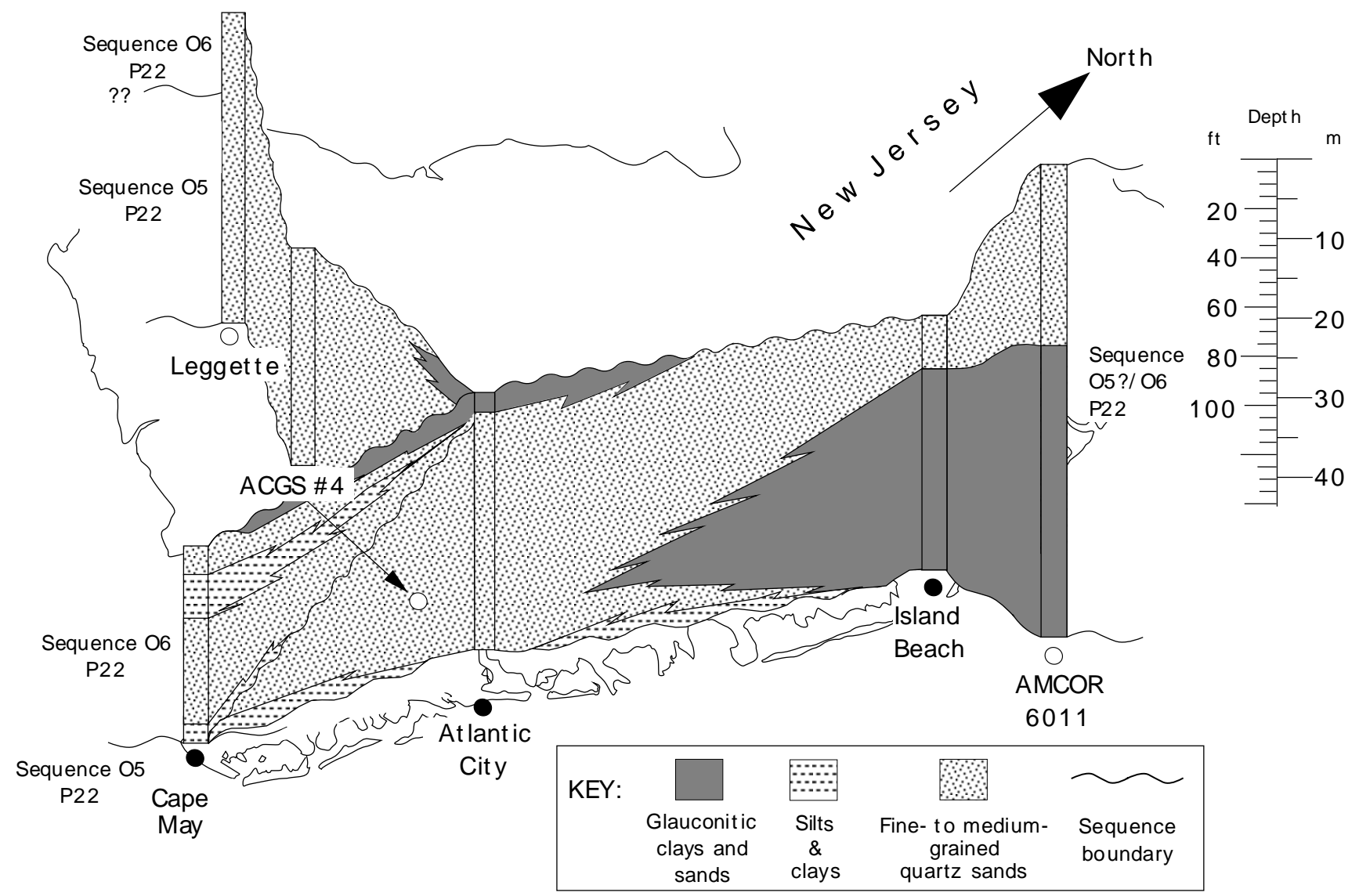

Figure 5. Fence diagram of Atlantic City Formation as observed in the 150X, Leggette, AMCOR 6011, and ACGS \#4 boreholes. The formation is divided into planktonic foraminiferal zones and New Jersey Oligocene sequences (from Pekar et al. [Chapter 15, this volume]). 